\title{
Age and growth of Hypophthalmus edentatus (Spix), (Siluriformes, Hypophthalmidae) in the Itaipu Reservoir, Paraná, Brazil
}

\author{
Ângela Maria Ambrósio ', Luiz Carlos Gomes ${ }^{1} \&$ Ângelo Antônio Agostinho ${ }^{1}$
}

${ }^{1}$ Núcleo de Pesquisas em Ictiologia, Limnologia e Aqüicultura (Nupélia), Universidade Estadual de Maringá, Departamento de Biologia. Avenida Colombo 5790, Bloco H-90, 87020-900 Maringá, Paraná, Brasil.

\begin{abstract}
Age and growth of Hypophthalmus edentatus (Spix, 1829) (Siluriformes, Hypophthalmidae) was determined. Data were collected from December 1983 to November 1984 and from April 1997 to March 1998 in the Itaipu Reservoir. To evaluate reading consistency, it was analyzed the coefficient of variation of the total length for each annulus observed in the otoliths. Through marginal increment analysis, it was determined that the annuli formed annually (April) indicating that otoliths may be used in the study of age and growth of the species. Food supply was considered the main factor affecting growth and annuli formation in both periods. Back-calculated data were used to assess if the Rosa Lee phenomenon, commom in selective samples like commercial fishing, occured. It was used also, the von Bertalanffy model to obtain the length growth curve. Parameters $\mathrm{k}$ and $\mathrm{L}_{\infty}$ were estimated by nonlinear regression for sexes separated. Although nom significant, k was greater in 1983-1984 than in 1997-1998. Inversely the $L_{\infty}$ was greater for females, but $k$ was smaller. Age at first maturation and annual instantaneous mortality (A) were similar in both sexes and years analyzed.
\end{abstract}

KEY WORDS. Age, growth, Hypophthalmus edentatus, Itaipu Reservoir, otoliths.

Age determination of fish in tropical regions is a challenge, given the fact that growth rings are not as evident as in temperate regions, where seasonal variation of temperature and luminosity are more conspicuous (SANTOS \& BARBIERI 1993). As a consequence, it is possible that events of secondary importance lead to the formation of marks that have clarity similar to seasonal ones used in age determination. This requires additional care in ring validation and data consolidation. Ring validation is not, however, a requirement restricted to determinations of the age of fish in tropical regions. CurTIs (1934) has discussed difficulties found during age evaluation of fish and he said that for some species, the first growth ring can not be identified, a fact demonstrated later by LENTSCH \& GrifFith (1987). Despite of the difficulties of this type of study, particularly in the tropical region, it is accepted that growth information is needed to the management of fishing resources (FerReira \& Russ 1994).

Given the importance of Hypophthalmus edentatus (Spix, 1829 ) in the commercial fishery of the Itaipu Reservoir (OKADA et al. 1996), the management of this resource must have to prioritize sustainability. The use of models that can simulate different scenarios resulting from alterations in effort or fishery strategy is highly desirable, for which growth curve parameters are necessary.

The objective of this paper was to determine periodicity, timing of growth rings formation in otoliths, to validate them as age rings and to estimate the growth in length of H. edentatus in the Itaipu Reservoir. Additionally, other population parameters as age at $\mathrm{L}_{50}, \mathrm{~L}_{100}$, the annual total mortality rate for the species in the Itaipu Reservoir was estimated. Comparisons for all parameters estimated between the years were done.

\section{MATERIAL AND METHODS}

\section{Study Area}

The Itaipu Reservoir $\left(24^{\circ} 05^{\prime}-25^{\circ} 33^{\prime} \mathrm{S}, 54^{\circ} 00^{\prime}-54^{\circ} 37^{\prime} \mathrm{W}\right)$, closed in 1982 is located in the Paraná River, on the BrazilParaguay border. The reservoir covers an area of $1,350 \mathrm{Km}^{2}$ and it presents an average depth of $21 \mathrm{~m}$ with a maximum of 170 $\mathrm{m}$. Hydraulic retention time is 40 days and flow fluctuates at about $8,200 \mathrm{~m}^{3} \mathrm{~s}^{-1}$. It is $150 \mathrm{~km}$ long and presents a well-defined longitudinal gradient (fluvial, transition and lacustrine) (Agostinho et al. 1995).

\section{The species}

Hypophthalmus edentatus was rarely caught in the commercial fishery before the formation of the Itaipu Reservoir, becoming abundant thereafter (Agostinho et al. 1994). It presents some characteristics that granted its success in the colonization of the reservoir such as: (I) a filter-planktophagous food habit (LANSAC-TôHA et al. 1991); (II) daily vertical migrations associated with feeding and predators avoidance, concentrating 
at the surface at night (Agostinho et al. 1994); (III) multiple spawning that extends from October to March in various areas of the reservoir (AgostinHo et al. 1997) and, (IV) planktonic eggs and larvae (NAKATANI et al. 2001). It is currently one of the most important species in the commercial fishery carried out in the reservoir, surpassing the annual average of $400 \mathrm{t}$ from 1988 to 1993 (ОкаDA et al. 1996). The catch is essentially performed with $8 \mathrm{~mm}$-streched mesh gill nets operated at the surface and at night, with the purpose of reducing the capture of juveniles of other species (AgostinHo et al. 1994).

\section{Collection of data, preparation of material and readings}

H. edentatus individuals used in this study were caught in gillnets $7.0 \mathrm{~cm}$ and $8.0 \mathrm{~cm}$ mesh size in the Itaipu Reservoir from December 1983 to November 1984 (experimental fishery) and from April 1997 to March 1998 (commercial fishery). The fish were measured (total length) and their otoliths were extracted, cleaned, dried and packed inside envelopes. Subsamples of three individuals per length class (class interval of $3.5 \mathrm{~cm}$ from 1983-1984, $3.3 \mathrm{~cm}$ from 1997-1998) for each sex and month were used to determine age. When necessary, the otoliths were sectioned and polished to improve visualization of age rings. The identification of the rings was done directly using a stereoscopic microscope. Three readings were carried out and the more frequent number of rings was considered the final result. When results were not similar in at least two readings, the individual was not considered in the analysis and it was replaced by another.

\section{Data analysis}

Consistency of the readings was evaluated through the coefficient of variation (CV) for the total lengths average of each age class observed in the otoliths, considering the sexes separately. CV is a statistically sound measure of ageing precision of fishes, but it may be influenced by the species, structure analysed, the age reader, so there is no a priori value of precision which can be designated as a target level for ageing studies (CAMPana 2001).

Ring validation was done through marginal increment analysis, which is an indirect validation method (LaI et al. 1996). Back-calculated data (based on FRANCIS 1990) were used for assess the Rosa Lee phenomenon (RicKer 1975). It occurs when a larger fraction of the larger fish die. The Rosa Lee phenomenon can be detected when back-calculation of length it earlier ages made from scales or otoliths, using samples that are representative of the whole of each age group involved (RICKER 1975). Age and length data, in which the Rosa Lee phenomenon was observed, were not included in the calculation of growth curve parameters (SMALE \& TAYLOR 1987).

Growth in length was determined for separated sexes using the von Bertalanffy model (Berveton \& Holt 1957), expressed by the following equation: $\mathrm{Tl}=\mathrm{L}_{\infty}\left[1-\mathrm{e}^{-\mathrm{k}\left(\mathrm{t}-\mathrm{t}_{0}\right)}\right]$, where: (Tl) average of total length $(\mathrm{cm})$ of individuals with age " $\mathrm{t}$ ", $\left(\mathrm{L}_{\infty}\right)$ total asymptotic length $(\mathrm{cm}),(\mathrm{k})$ parameter related to growth rate $\left(\right.$ year $\left.^{-1}\right)$, ( $t$ ) age of individuals, $\left(t_{0}\right)$ length of individuals at the moment of birth.

In order to obtain the parameters for the von Bertalanffy model, a nonlinear procedure was used (KING 1995). There are many examples of nonlinear models and in every one the least squares technique is extensively used. The literature is rich in algorithms for minimization of the residual sum of squares in nonlinear model situations, but the most procedure used in softwares is the Gauss-Newton (MYers 1990). This is iterative and requires starting value (seeds) for the parameters (MYERS 1990). In this paper, the initial parameter values necessary for the nonlinear procedure were obtained through Ford-Walford transformation. The value of $t_{0}$ was considered zero, following the same procedure used by Santos (1978), Hammers \& Miranda (1991) and Orsi \& ShibatTa (1999). Moreau (1987) says that $\mathrm{t}_{0}$ is not a biological paremeter, but only an artifact to become the growth curves adjustment more adequate.

Considering the possibilities that the first ring cannot be identified or it is not formed in the first year of life, as registered in other fish species (CURTIs 1934, LeNTSCH \& GRIFFITH 1987), the best adjustment of the lagging age data was sought. The lags considered were one, which means the formation of the first ring at age two; and two, which means the formation of the first ring at age three. Nonlinear procedure was applied to both. The model that presented the smallest squared sum of the residues (SSR in ANOVA terminology) and more reasonable values for the parameters of the von Bertalanffy model was considered the best. For comparisons, growth curve parameters were also calculated based on Ford-Walford transformation. Also, the asymptotic standard erros of the estimate $\left(\mathrm{K}, \mathrm{L}_{\infty}\right)$ were obtained to evaluate diferences between years and sexes.

Age at first maturation was obtained by the von Bertalanffy equation, considering first maturation length obtained by "Nupélia (Núcleo de pesquisa em limnologia, ictiologia e aqüicultura)". Annual total mortality (A) was estimated from total mortality (Z) (RICKER 1975). It was necessary to obtain ages at each length for every individual through the formula $t=\ln [(1-$ $\left.\left.\mathrm{L}_{\mathrm{t}} / \mathrm{L}_{\infty}\right)\right] /-\mathrm{K}$. Once age was estimated, frequency of individuals in each age class was obtained, along with the catch curve for males and females in the two cycles studied. Descending points on this graph were used in a regression analysis and the slope of the regression (b) was equivalent to the value of $\mathrm{Z}$ (total mortality). Annual total mortality was then calculated from this value using the following formula: $\mathrm{A}=1-\mathrm{e}^{-2}$ (RICKER 1975).

\section{RESULTS}

\section{Reading and validation}

The number of otoliths analyzed in the first period was 144 (65 males and 79 females), with total length ranging from $11.5 \mathrm{~cm}$ to $46.5 \mathrm{~cm}$. In the second period, 112 (50 males and 62 females) were analyzed with total length ranging from $17.5 \mathrm{~cm}$ to $50.5 \mathrm{~cm}$ (Tab. I).

The coefficients of variation (CV), in general, were less than 19\% demonstranting a good consistency of the readings. CVs decreased with the increase in the number of rings and were higher in the first period. In the two periods, the maximum number of rings was five. The lowest averages marginal increment in the otoliths were observed in April 1984 and April 1997 , indicating that the rings are formed at this time, annually (Fig. 1).

\section{Back-calculation}

Comparisons between back-calculated and observed lengths (direct method) in each age presented considerable differences, revealing the Lee's phenomenon in the two periods and in both sexes. This difference was greater in younger individuals specially in the second period (1997-1998) (Fig. 2). 

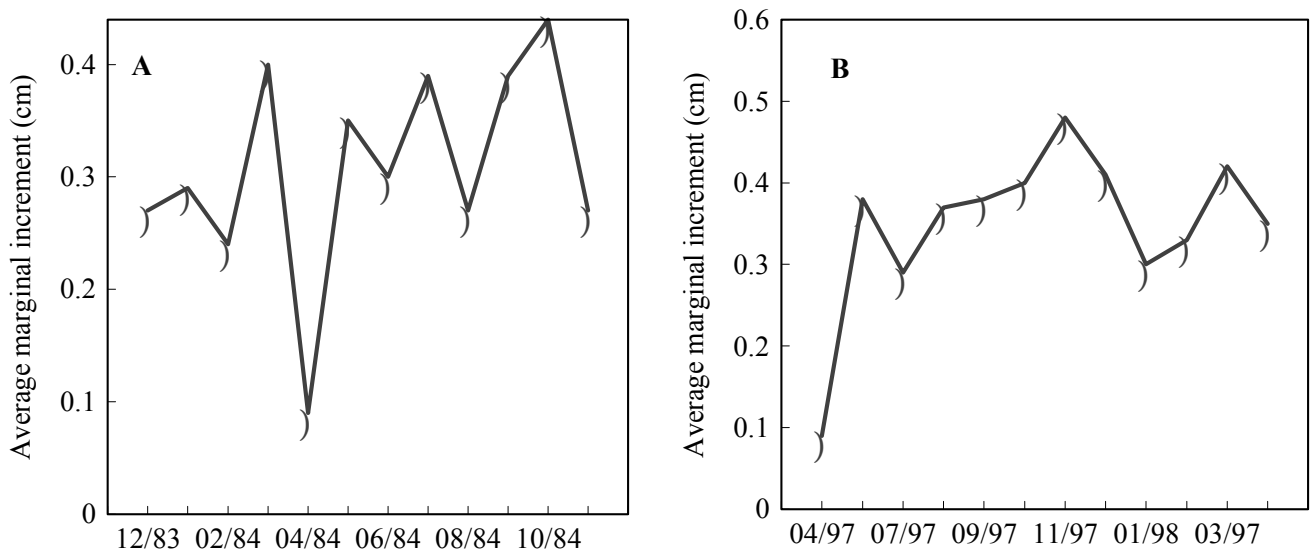

Figure 1. Monthly variation in the average marginal increment in otoliths of $H$. edentatus in the periods 1983-1984 (A) and 1997-1998 (B).

Table I. Sample size $(\mathrm{N})$, average total length $(\mathrm{Tl}, \mathrm{cm})$ and coefficient of variation $(\mathrm{CV}, \%)$ of the total length per growth ring in $\mathrm{H}$. edentatus otoliths in 1983-1984 and 1997-1998.

\begin{tabular}{|c|c|c|c|c|c|c|}
\hline \multirow{2}{*}{$\begin{array}{l}\text { Years } \\
\text { Rings }\end{array}$} & \multicolumn{3}{|c|}{ 1983-1984 } & \multicolumn{3}{|c|}{ 1997-1998 } \\
\hline & $\mathrm{N}$ & $\mathrm{TI}$ & CV & $\mathrm{N}$ & $\mathrm{Tl}$ & CV \\
\hline \multicolumn{7}{|l|}{ Males } \\
\hline 0 & 8 & 17.5 & 18.1 & & & \\
\hline 1 & 19 & 22.3 & 15.6 & & & \\
\hline 2 & 30 & 30.1 & 10.3 & 5 & 32.3 & 11.9 \\
\hline 3 & 8 & 34.0 & 7.1 & 8 & 36.0 & 7.5 \\
\hline 4 & & & & 34 & 37.9 & 4.5 \\
\hline 5 & & & & 3 & 37.5 & 3.5 \\
\hline \multicolumn{7}{|l|}{ Females } \\
\hline 0 & 3 & 15.6 & 13.1 & & & \\
\hline 1 & 15 & 23.5 & 18.4 & & & \\
\hline 2 & 33 & 29.1 & 10.0 & 8 & 33.8 & 5.8 \\
\hline 3 & 22 & 36.4 & 8.5 & 5 & 36.0 & 4.1 \\
\hline 4 & 6 & 42.6 & 7.3 & 39 & 38.3 & 5.8 \\
\hline 5 & & & & 10 & 43.7 & 8.6 \\
\hline
\end{tabular}

Although the back-calculated average total length were inferior to the averages obtained through the direct method, they followed the same tendencies, indicating that females reached greater sizes than males in the two studied periods.

\section{Fit of the Von Bertalanffy model}

Fit of the von Bertalanffy model, using nonlinear procedure, showed that the best model (smallest squared sum of the residuals) was obtained lagging the data of the readings in one ring (Tab. II). Thus, the first ring would be associated with two years of age for both sexes in the two periods.
An asteriscus otolith from an individual with total length of $27.8 \mathrm{~cm}$ is showed in figure 3 .

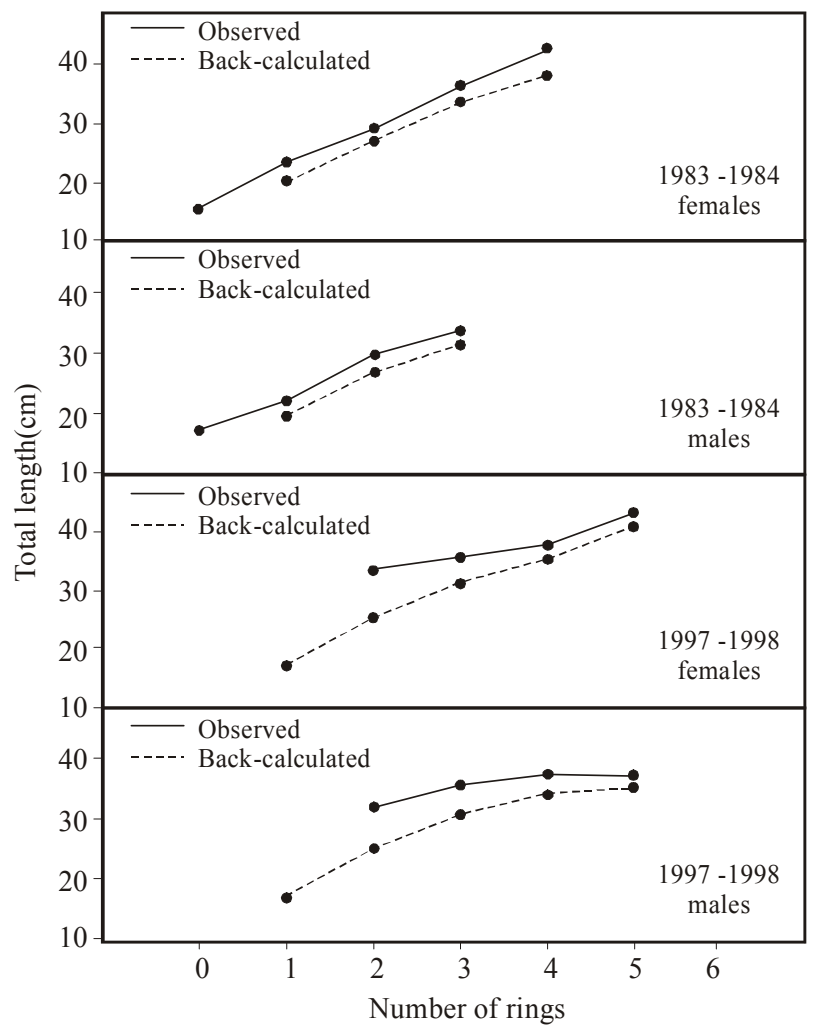

Figure 2. Representation of observed lengths (direct method) and back-calculated lengths (back-calculation method) in males and females for both periods (1983-1984 and 1997-1998) in otoliths of $H$. edentatus. 
Table II. Growth parameters estimated for the Bertalanffy model through nonlinear regression and by Ford-Walford transformation. Three scenarios are considered in the estimates by nonlinear regression: zero, one and two rings absent. (SST) Sum of the squared totals corrected, (SSR) sum of the squared residuals.

\begin{tabular}{|c|c|c|c|c|c|c|}
\hline \multirow{2}{*}{ Rings absent (lag) } & \multicolumn{4}{|c|}{ Non linear regression } & \multicolumn{2}{|c|}{ Ford-Walford } \\
\hline & K & $\mathrm{L}_{\infty}$ & SST & SSR & K & $\mathrm{L}_{\infty}$ \\
\hline \multicolumn{7}{|l|}{ Males 1983-1984 } \\
\hline 0 & 0.85 & 33.8 & 70.6 & 0.92 & 0.10 & 81.3 \\
\hline 1 & 0.27 & 48.5 & 70.6 & 0.12 & & \\
\hline 2 & 0.06 & 125.9 & 70.6 & 0.72 & & \\
\hline
\end{tabular}

Females 1983-1984

$\begin{array}{rrrrrrr}0 & 0.61 & 40.7 & 182.8 & 6.34 & 0.06 & 137.2 \\ 1 & 0.21 & 59.2 & 182.8 & 0.17 & & \\ 2 & 0.05 & 149.9 & 182.8 & 0.98 & & \end{array}$

Males 1997-1998

$\begin{array}{rrrrrrr}0 & 0.58 & 38.1 & 169.2 & 1.69 & 1.16 & 37.8 \\ 1 & 0.19 & 57.3 & 169.2 & 1.19 & & \\ 2 & 0.04 & 180.2 & 169.2 & 3.81 & & \end{array}$

Females 1997-1998

\begin{tabular}{rrrrrrr}
0 & 0.33 & 51.9 & 576.9 & 15.47 & 0.52 & 31.3 \\
1 & 0.12 & 79.6 & 576.9 & 1.74 & & \\
2 & 0.03 & 247.4 & 576.9 & 4.61 & & \\
\hline
\end{tabular}

Two growth rings are present, corresponding to a threeyears-old individual. Then, the equations that describe the growth of $H$. edentatus for the different sexes and periods are: males 1983-1984: $\mathrm{Tl}=48.5\left[1-\mathrm{e}^{-0.27 . t}\right]$, males 1997-1998: $\mathrm{Tl}=$ $57.3\left[1-\mathrm{e}^{-0.19 . t}\right]$, females $1983-1984: \mathrm{Tl}=59.2\left[1-\mathrm{e}^{-0.21 . t}\right]$ and females 1997-1998: $\mathrm{Tl}=79.6\left[1-\mathrm{e}^{-0.12 . t}\right]$.

Graphic representations of these equations are shown in figure $4 \mathrm{~A}$ and $4 \mathrm{~B}$.

\section{Growth and other population parameters}

The $\mathrm{k}$ values were highest in 1983-84, and $\mathrm{L}_{\infty}$ the lowest, which was expected because they are inversely correlated. But they did not vary significantly $\left(95 \%\right.$ confidence interval for $\mathrm{L}_{\infty}$ and K overlapped) (Tab. III). Females reached greater asymptotic length than males and lower $k$ values. Annual instantaneous mortality (A) varied slighty between periods. The same trend was verified for the age where all are adults and first maturation age $\left(\mathrm{L}_{100}\right.$ and $\left.\mathrm{L}_{50}\right)$.

\section{DISCUSSION}

Ring validation in age and growth studies is essential in regions where climatic conditions are less variable, resulting in less clear otolith marks (CASSELMAN 1983, BeAmISH \& McFarLane 1983, Cyterski \& Spangler 1996, Jepsen et al. 1999). In the present study, low coefficient of variation values attest to the consistency of the reading of the growth rings, showing that

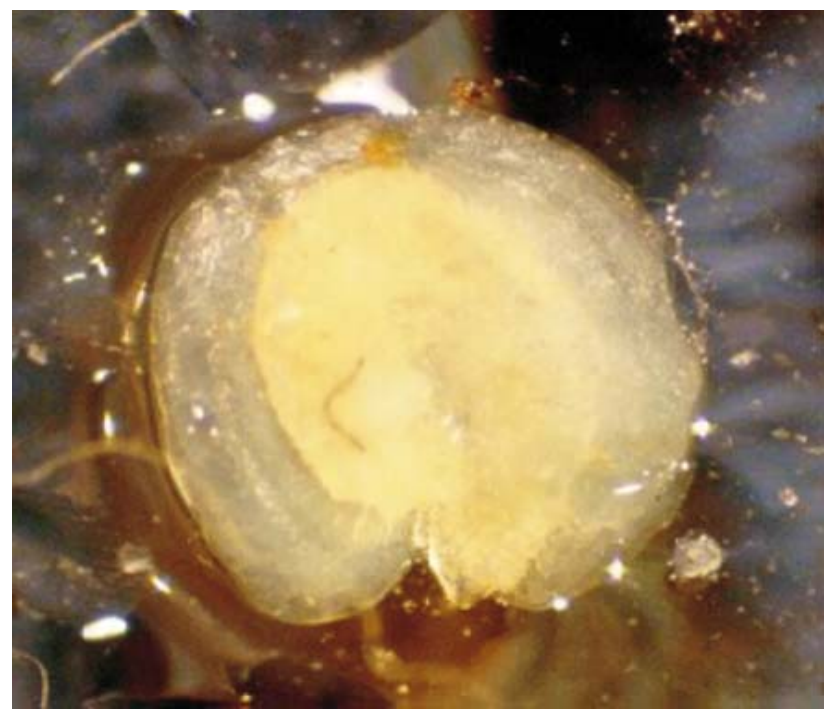

Figure 3. Asteriscus otolith with radius equal to $1.20 \mathrm{~mm}$ of a fish with total length of $27.8 \mathrm{~cm}$ (individual number 10559).

Table III. Parameter estimated for the Bertalanffy model (K e $L \infty)$, annual instantaneous mortality rate (A), first maturation length (L50), length at which all individuals have reproduced at least once (L100), and estimated ages for males and females of $H$. edentatus from the Itaipu Reservoir in the two periods studied. Values in brackets are the asymptotic standard error of the estimates for the Bertalanffy model.

\begin{tabular}{lccccc}
\hline & \multicolumn{2}{c}{ Males } & & \multicolumn{2}{c}{ Females } \\
\cline { 1 - 2 } \cline { 5 - 6 } Variables & $1983-1984$ & $1997-1998$ & & $1983-1984$ & $1997-1998$ \\
\hline K (year-1) & $0.27(0.15)$ & $0.19(0.07)$ & & $0.21(0.07)$ & $0.12(0.11)$ \\
L $(\mathrm{cm})$ & $48.5(5.15)$ & $57.3(1.0)$ & $59.2(8.15)$ & $79.6(4.46)$ \\
A (\%) & 65 & 59 & & 68 & 65 \\
L50 (cm /years) & $25 / 2$ & $25 / 3$ & & $25.4 / 2$ & $25.4 / 3$ \\
L100 (cm/years) & $30 / 3$ & $30 / 3$ & $30 / 3$ & $30 / 3$ \\
\hline
\end{tabular}

otoliths can be used to estimate age and growth of $H$. edentatus. Collection and preparation of otoliths for analysis is complicated and requires attention, but they are more adequate because they present distinct marks and realistic interpretations (Rossi-Wongtschowski et al. 1982, Casselman 1983, Sweatman \& KOHLER 1991). The material deposited on otoliths is rarely ever altered or reabsorbed (CAMPANA \& CASSELMAN 1993). HAMmERS \& Miranda (1991) demonstrated in studies with otoliths that they hardly ever present false growth rings. Ages estimated in this study are precise. This can be verified by the high agreement of the age data obtained when two readers carried out independent readings (91\% agreement).

The formation of only one growth ring a year is considered common in the neotropical region (ReINA et al. 1995, AMBRósIo \& HAYASH 1997). Apposition marks in bony structures of tropical species has been associated with the reproductive 

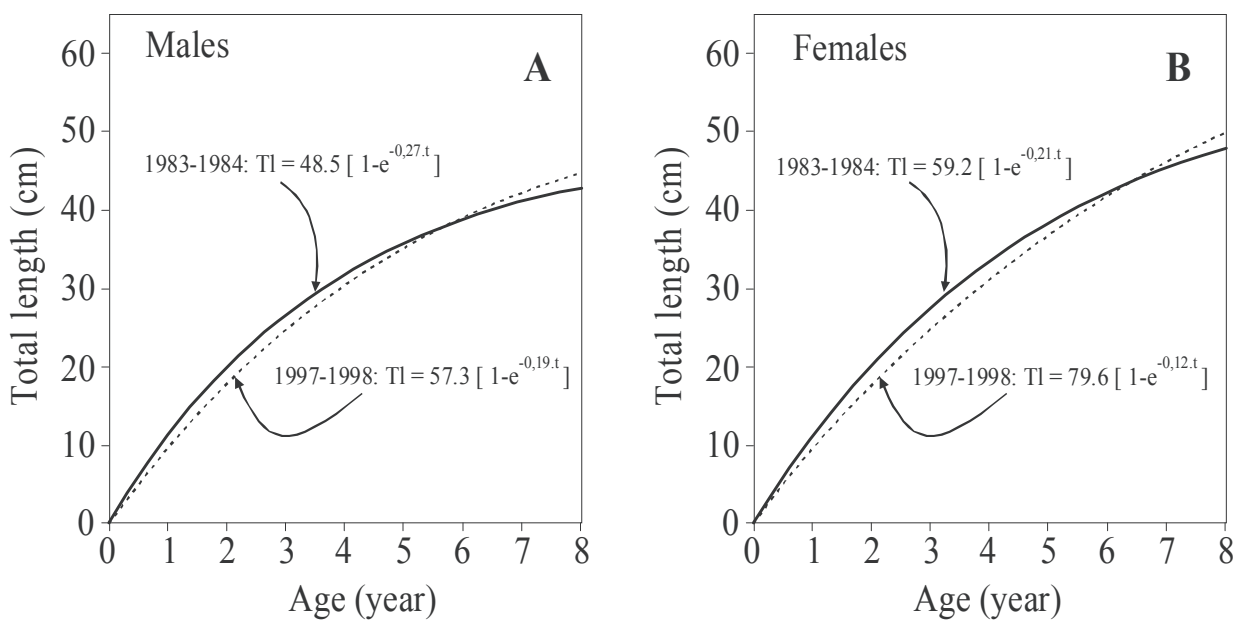

Figure 4. Representatios of the growth curves in length for males (A) and females (B) of $H$. edentatus in the Itaipu Reservoir for both periods (1983-1984, 1997-1998).

process (BOWERING 1978). Reproduction in temperate regions is associated with suspension of feeding or its decrease during spawning, and it results in lower growth rates. GOULART \& VERANI (1992) studying fish from the neotropical region attributed the reduction of growth to the diversion of energy and somatic reserves for the preparation of sexual products and spawning. GJOESAETER et al. (1984) and JEPSEN et al. (1999), analyzing tropical fish, related the existence of growth synchronization and spawning to reduced growth rates. In tropical latitudes, temporal matching of the floods and environmental factors associated with the reproductive process and its influence on the rate of food consumption make it difficult to identify the factor responsible for ring formation. Even when ring formation occurs outside of the spawning period, it has been at least partially caused by reproductive cycle demands. Gonadal maturation, fall in water temperature and parental care are the main determinant factors of slow growth for Gymnogeophagus lacustris (HARTZ et al. 1998). The spawning period of H. edentatus is from October to March. Ring formation occurred in the period immediately after. We know that $H$. edetantus has planktonic eggs (NAKATANI et al. 2001) and that the gonads are at rest or recovering after March, therefore, a relevant effect of the reproductive cycle on the growth rate and ring formation is not expected. On the other hand, the Itaipu Reservoir water flow increases at this period, restricting primary production, through light limitation, and diluting zooplankton density (Gomes \& Miranda 2001). The retraction in food availability during the high flow period seems to be an important factor in ring formation of $H$. edentatus otoliths.

The coefficient of variation values of the average total length of each growth ring class registered in the otoliths decreased with the increase in the number of rings found. The decrease in the coefficient of variations of the average total length may be the result of fishing equipment selectivity and shoal formation behavior (WITHERELL \& BuRNETT 1993). The shoal formation strategy of this species was observed during the studies and is described by Carvalho (1978) and Carvalho \& Merona (1986). This and the fact that the sampling gear (gillnets), which in the first period had meshes varying one centimeter for mesh sizes smaller than $6 \mathrm{~cm}$ and two centimeters in subsequent sizes, may have influenced values of the coefficient of variation. However, the low values presented by this coefficient were verified in all ages, attesting to its consistency in age determination.

Absence of the first ring in the otolith, inferred from nonlinear adjustment of the parameters $\left(\mathrm{K}\right.$ and $\left.\mathrm{L}_{\infty}\right)$, was mentioned by CurTis (1934), for three species of trout (Salmo whitei, $S$. roosevetti and $S$. agua-bonita), and discussed later by LENTSCH \& GRIFFITH (1987) in relation to other salmonids. This may due to very accelerated growth in the first year and so the first ring is occulted. Stronger evidence that the first ring in $H$. edentatus (Itaipu Reservoir) cannot be identified, was the fact that the tendencies of better adjustment was obtained with the retarding of a ring in both years studied. Thus, data obtained through nonlinear adjustment were more adequate when the first ring in the otoliths was not considered. Food availability, shown by the high biomass of this species in the Itaipu Reservoir, and not energy expenditure on reproduction in the initial phases, could explain the possibility of the first ring could not be identified.

Asymptotic length values were greater than the maximum values observed $(46.5 \mathrm{~cm}$ in $1983-1984$ and $50.5 \mathrm{~cm}$ in 1997-1998). This can be explained by fishing equipment selectivity, more evident in the year 1997-1998, when the data available for the analyses arose from the commercial fishery, which used mainly gillnets with $8 \mathrm{~cm}$ mesh stretch.

Back-calculation analysis showed the existence of the Rosa Lee phenomenon, broadly discussed by RICKER (1975) and SMALE \& TAYLOR (1987), among others. The main reason for the occurrence of this phenomenon, in populations unexploited by fishery, is the fact that fish with fast growth frequently tend to age prematurely, becoming worn-out earlier and dying before those with slow growth from the same spawning. In this study, where the fishery is intense, the existence of the Rosa Lee phenomenon should result from recruitment and fishing equipment selectivity (RICKER 1975, LENTSCH \& GRIFFITH 1987).

Revista Brasileira de Zoologia 20 (2): 183-190, junho 2003 
Thus, members of one age class that grow more quickly, become prematurely vulnerable to fishing equipment, and are caught before than the individuals with normal growth are totally vulnerable. In addition, two other natural situations may lead for the phenomenon; however, in opposite directions. The first is that there is strong evidence that during the first year of life, small-sized slow growth individuals are more susceptible to predation. Such selective mortality during the first year not affect any back-calculated datum because back calculation can be used only after the formation of the first ring. However, if the same situation persists in the second year or later, the phenomenon can be seen. The second one, can occur if fish of both sexes were sampled and analyzed together; but in fact, there are differences in growth and natural mortality rates. This sometimes makes observation of the phenomenon difficult or a reverse Rosa Lee effect may be observed (RICKER 1975). It should be emphasized that age and length data, where the Rosa Lee phenomenon was detected, were not included in the growth calculation and, therefore, were not incorporated into the growth curves. This procedure is common when trying to correct errors arising from the back-calculation method (SMALE \& TAYLOR 1987).

Besides not significant, the little variation in growth of H. edentatus, when different sexes and years are considered (Tab. III), may be related to the trophic upsurge period, which occurs in the first years after the reservoir filling (Agostinho et al. 1999a). Incorporation of high biomass, especially plants, resulting from flooding, increases the availability of nutrients, causing population explosions of algae and herbivorous zooplankton, the main food of the species (CARVALHO 1980, LANSACTôHA et al. 1991).

Annual total mortality values varied between $59 \%$ and $68 \%$ and were considered low. Low mortality value was also by Hammers \& Miranda (1991) for Pomoxis annularis in North American lakes. Although variation in mortality can be explained by such diverse factors as age, density, illnesses, parasites, food supply, abundance of predators, water temperature, fishery pressure, sex and size (VetTer 1988), there is evidence that in the H. edentatus stock of the Itaipu Reservoir, the fishery and predation were predominant factors. Predation is considered to be the most important factor with direct influence on mortality (VetTer 1988). Increase in abundance of the "curvina", Plagioscion squamosissimus, verified during the years (Agostinho et al. 1999b), seems to be related because H. edentatus constituted the main item consumed by this species in internal areas of the Itaipu Reservoir (HAHN et al. 1997). Agostinho \& Julio Jr. (1996) described an inverse relationship between the density of these two species in different years. The exploitation of $H$. edentatus by the fishery effectively began in 1987, two years after the removal of fishery restrictions, when methods for its capture were disseminated and its acceptance in the consumer market was consolidated (AgostinHo et al. 1999b). It was the main species in the landings for almost ten years, being subjected to strong fishery pressure.

As regards to age at $\mathrm{L}_{100}$ (age where $100 \%$ of individuals reached maturity) and $\mathrm{L}_{50}$ (age where $50.0 \%$ of individuals reached maturity), data estimated showed that in the period 1983-1984, individuals reached maturity one year before those in the period 1997-1998 (Tab. III). This may be another sign that in the first year after the formation of the Reservoir, environmental conditions were highly favorable to the development of $H$. edentatus.

\section{ACKNOWLEDGEMENTS}

The authors are most grateful to the researchers and students of Núpelia "Núcleo de Pesquisa em Ictiologia, Limnologia e Aqüicultura" and PEA "Curso de Pós-graduação em Ciências Ambientais" for their help and assistence in all phases of this research. We thank the Itaipu Binacional for their help when sampling the Itaipu Reservoir.

\section{REFERENCES}

Agostinho, A.A.; E. Benedito-Cecilio; L.C. Gomes \& A.A. Sampaio. 1994. Spatial and temporal distribution of sardela, Нуроphthalmus edentatus (Pisces, Siluroidei), in the area of influence of the Itaipu Reservoir (Paraná, Brazil). Revista UNIMAR, Maringá, 16 (Supl. 3): 27-40.

Agostinho, A.A.; A.E.A. de M. Vazzoler \& S.M. Thomaz. 1995. The high River Paraná basin: Limnological and ichthyological aspect, p. 59-103. In: J.G. Tundisi; C.E.M. BICUdo \& M. Matsumura-Tundisi (Eds) Limnology in Brazil. Rio de Janeiro, Academia Brasileira de Ciências, Sociedade Brasileira de Limnologia, 376p.

Agostinho, A.A. \& H.F. Júlıo JR. 1996. Ameaça ecológica - peixes de outras águas. Ciência Hoje, Rio de Janeiro, 21 (124): 36-44.

Agostinho, A.A.; L.E. Miranda; L. M. Bini; L. C. Gomes; S. M. Thomaz \& H. I. Suzuki. 1999a. Patterns of colonization in neotropical reservoirs, and prognoses on aging, p. 227-265. In: J.G. TUNDISI \& M. STRASKRABA (Eds) Theoretical reservoir ecology and its applications. São Carlos, Backhuys Publishers, 585p.

Agostinho, A A.; E.K. Okada \& J. Gregoris. 1999b. A pesca no reservatório de Itaipu aspectos socioeconômicos e impactos do represamento, p. 279-320. In: R. HenRy (Ed.). Ecologia de reservatórios: estrutura, função e Aspectos Sociais. Botucatu, FUNDIBIO, FAPESP, 799p.

Ambrósio, A.M. \& C. Hayashi. 1997. Idade e crescimento de Steindachnerina insculpta (Fernandes-Yepes, 1948), (Characiformes, Curimatidae) da planície de inundação do alto rio Paraná, Brasil. Revista Brasileira de Biologia, Rio de Janeiro, 57 (4): 687-698.

Beamish, R.J. \& G.A. McFarlane. 1983. The forgotten requirement for age validation in fisheries biology. Transactions of the American Fisheries Society, Bethesda, 112 (6): 735-743.

Beverton B. J.H. \& S.J. Holt. 1957. On the dynamics of exploited fish populations. London, Chapman \& Hall, 533p.

BoweriNG, W.R. 1978. Age and growth of the Greenland Halibut, Reinhardtius hippoglossoides (Walbaum), in Icnaf subareas 24. Research Bulletin of the International Commission for the Northwest Athantic Fisheries, Dartmouth, 13: 5-10.

CAMPANA, S.E. 2001. Accuracy, precision and quality control in age determination, including a review of the use and abuse of age validation methods. Journal of Fish Biology, London, 59: 197-242.

Campana, S.E. \& J.M. Casselman. 1993. Stock discrimination using otolith shape analysis. Canadian Journal of Fisheries and Aquatic Sciences, Ottawa, 50: 1062-1083.

Carvalho, J.L. 1978. Contribuição ao conhecimento da biologia do mapará Hypophthalmus perporosum COPE 1878-(Pisces: Hypophthalmidae) no baixo e médio Tocantins. Boletim 
da Facudade de Ciências Agrárias do Pará, Belém, 10: 3957.

Carvalho, J.L. \& B. Merona. 1986. Estudos sobre peixes migratórios do baixo Tocantins, antes do fechamento da barragem de Tucurui. Amazoniana, Manaus, 9 (4): 595-607.

Carvalho, F.M. 1980. Alimentação do mapará (Hypophthalmus edentatus, Spix, 1829) do lago do Castanho (Siluriformes, Hypophthalmidae). Acta Amazônica, Kiel, 10 (3): 545-555.

Casselman, J.M. 1983. Age and growth assessment of fish from theirs calcified structures - techniques and tools. In: E.P. Princes \& L.M. Qules (Eds). Proceedings of the international workshop on age determination of oceanic pelagic fishes: Tuna Billfishes, and thanbs. NOAA, Tech. Rep. NMFS 8, 211p.

CuRTIS, B. 1934. The golden trout of Cottonwood lakes (Salmo agua-bonita Jordan). Transactions of the American Fisheries Society, Bethesda, 64: 259-265.

Cyterski, M.J. \& G.R. Spangler. 1996. A tool for age determination. North American Journal of Fisheries Management, Bethesda, 16: 403-412.

Ferreira, B.P. \& G.R. Russ. 1994. Age validation and estimation of growth rate of the coral trout, Plectropomus leopardus, (Lacepede, 1802) from Lizard Island, Northern Great Barrier Reef. Fishery Bulletin, Seathe, 92 (1): 46-57.

Francis, R.I.C.C. 1990. Back-calculation of fish length: a critical review. Journal of Fish Biology, London, 36: 883-902.

Gjoesaeter, J.; P. Dayaratne; O.A. Bergstad; H. Gjoesaeter; M.I. SOUZA \& I.M. BЕСK. 1984. Ageing tropical fish by growth rings in the otoliths. FAO Fisheries Circular, Rome, 776.

Gomes, L.C. \& L.E. Miranda. 2001. Hydrologic and climatic regimes limit phytoplankton biomass in reservoirs of the Upper Paraná River basin, Brazil. Hydrobiologia, Dordrect, 457: 205-244.

Goulart, E. \& J.R. Verani. 1992. Idade e crescimento do cascudo, Hypostomus commersonii Valenciennes, 1840 (OsteichthyesLoricariidae) da represa Capivari-Cachoeira, Paraná, Brasil. Revista UNIMAR, Maringá, 14, supl.: 1-17.

Hahn, N.S.; A.A. Agostinho \& R. Goiten. 1997. Feeding ecology of "curvina" Plagioscion squamosissimus (Heckel, 1840) (Osteichthyes, Perciformes) in the Itaipu Reservoir and Porto Rico floodplain. Acta Limnologica Brasiliensia, Porto Alegre, 9: 11-22.

Hammers, B.E. \& L.E. Miranda. 1991. Comparison of methods for estimating age, growth, and related population characteristics of white crappies. North American Journal of Fisheries Management, Bethesda, 11: 492-498.

Hartz, S.M.; W.R. Bruschi Jr. \& M.V. Formehl. 1998. Idade e crescimento de Gymnogeophagus lacustris Reis \& Malabarba, um cichlidae endêmico da bacia hidrográfica do rio Tramandaí, Rio Grande do Sul, Brasil. Revista Brasileira de Zoologia, Curitiba, 15 (3): 605-612.

Jepsen, D.B.; K.O. Winnemiller; D.C. Taphorn \& D.R. Olarte. 1999. Age structure and growth of peacock cichlids from rivers and reservoirs of Venezuela. Journal of Fish Biology, London, 55: 433-450.

KING, M. 1995. Fisheries biology, assessment and management. Oxford, Osney Mead. Fishing News Books, 341p.

Lai, H.L.; V.F. Gallucci; D.R. Gunderson \& R.F. Donnelly. 1996.
Age determination in fisheries: Methods and applications to stock assessment, p. 82-170. In: V.F. GallucCI; S.B. SAILA; D.J. Gustafson \& B.J. Rothschild (Eds) Stock assessment: quantitative methods and applications for small-scale fisheries. Boca Rota, Lewis Publishers, 527p.

LANSAC-TÔHA, F.A.; A.F. Lima; N.S. Hahn \& I.F. AndRian. 1991. Composição da dieta alimentar de Hypophthalmus edentatus (Spix, 1829) (Pisces, Hypophthalmidae) no reservatório de Itaipu e no rio Ocoí. Revista UNIMAR, Maringá, 13 (2): 147-162.

LENTSCH, L.D. \& J.S. GRIFFITH. 1987. Lack of first-year annuli on scales: frequency of occurrence and predictability in trout of the western United States, p. 177-188. In: R.C. SUMMERFELT $\&$ G.E. Hall (Eds). Age and growth of fish. Iowa, Iowa State University Press, 544p.

Moreau, J. 1987. Mathematical and bilogica expression of growth in fishes: Recent trends and further developments, p. 87-113. In: R.C. Summerfelt \& G.E. Hall (Eds). The age and growth of fish. Iowa, Iowa State University Press, 544p.

Myers, R.H. 1990. Classical and modern regression with applications. BELMONT, Duxbury Press, $2^{\text {nd }}$ ed., $488 \mathrm{p}$.

Nakatani, K.; A.A. Agostinho; G. Baumgartner; A. Bialetzki; P.V. Sanches \& M. Cavicchioli. 2001. Ovos e larvas de peixes de água doce: desenvolvimento e manual de identificação. Maringá, Universidade Estadual de Maringá, Núpelia, Eletrobrás, 359p.

Okada, E.K.; A.A. Agostinho \& M. Petrere Jr. 1996. Catch and effort data and the management of the commercial fisheries of the Itaipu Reservoir in the upper Paraná River, Brazil, p. 154-161. In: I.G. Cowx (Ed.). Stock Assessment in Inland Fisheries. Oxford, Onesy Mead. Fishing News Books, 513p.

Orsi, M.L. \& O.A. Shibatta. 1999. Crescimento de Schizodon intermedius Garavelo \& Britski (Osteichthyes, Anostomidae) do Rio Tibagi (Sertanópolis, Paraná). Revista Brasileira de Zoologia, Curitiba, 16 (3): 701-710.

Reina, M.P.; H. Ramírez \& B.M. Valderrama. 1995. Edad y crescimiento de Paulicea luetkeni (Steindachner, 1876) (Pisces: Pimelodidae) basado en la lectura de estructuras duras (espinha de aleta pectoral) en el alto rio Meta (Colombia). Boletim Cientifíco do Instituto Nacional de Pesquisas da Amzônia, Manaus, 3: 115-135.

RICKER, W.E. 1975. Computation and interpretation of biological statistics of fish populations. Ottawa, Fisheries and Marine Service, Department of the Enviroment, 482p.

Rossi-Wongtschowski, C.L.B.; A.E.A. De M. Vazzoler \& F.M.S. BRAGA. 1982. Estudos sobre estrutura, ciclo de vida e comportamento de Sardinella brasiliensis (Steindachner, 1879), na área entre $22^{\circ} \mathrm{S}$ e $28^{\circ} \mathrm{S}$, Brasil. 1. Morfologia dos otólitos. Boletim do Instituto Oceanográfico, São Paulo, 31 (2): 59-76.

SANTOS, E.P. 1978. Dinâmica de populações aplicada a pesca e piscicultura. São Paulo, Ed. Hucitec, 129p.

Santos, G.B. \& G. Barbieri. 1993. Idade e crescimento do "piau gordura", Leporinus piau Fowler, 1941, na represa de Três Marias (Estado de Minas Gerais) (Pisces, Ostariophysi, Anostomidade). Revista Brasileira de Biologia, Rio de Janeiro, 53 (4): 649-658.

SMALE, M.A. \& W.W. TAYLOR. 1987. Sources of back-calculation 
error in estimating growth of lake whitefish, p. 189-202. In: Summerfelt, R.C. \& G.E. Hall (Eds). Age and growth of fish. Iowa, Iowa State University Press, 544p.

Sweatman, J.J. \& C. Kohler. 1991. Validation of daily otolith increments for young-of-the-year white crappies. North American Journal of Fisheries Management, Bethesda, 11:
499-503

VeTter, E.F. 1988. Estimation of natural mortality in fish stocks: A review. Fishery Bulletin, Seathe, 86 (1): 25-43.

Witherell, D.B. \& J. BurnetT. 1993. Growth and maturation of winter flounder, Pleuronectes Americanus, in Massachusetts. Fishery Bulletin, Seathe, 91 (4): 816-820.

Received in 26.IX.2002; accepted in 25.IV.2003.

Revista Brasileira de Zoologia 20 (2): 183-190, junho 2003 